\title{
Economic outlook of rice crops in Pakistan: a time series analysis (1970-2015)
}

\author{
Abdul Rehman ${ }^{1 *}$, Luan Jingdong ${ }^{1}$, Abbas Ali Chandio ${ }^{2}$, Muhammad Shabbir ${ }^{3}$ and Imran Hussain ${ }^{4}$
}

\author{
* Correspondence: \\ Zayan78611@yahoo.com; \\ abdulrehman@ahau.edu.cn \\ ${ }^{1}$ College of Economics and \\ Management, Anhui Agricultural \\ University, Hefei, Anhui, China \\ Full list of author information is \\ available at the end of the article
}

\begin{abstract}
Background: The basic objective of this study was to examine the relationship between the rice output, its production area, water availability, and agricultural gross domestic product (GDP) of Pakistan. Annual time series data for 1970-2015 were collected from the National Food Security and Research, Economic Survey of Pakistan, and Pakistan Bureau of Statistics (various publications).

Methods: Rice crop data were analyzed using the ordinary least square method and the augmented Dickey-Fuller test. Were interpreted using the Johansen cointegration test.

Results: Our study revealed the existence of a long-standing relationship between rice output, its production area, and water availability with the agricultural GDP of Pakistan. Regression results indicate that rice output and cultivated area have a significant and positive relationship with agricultural GDP, while water availability has a negative relationship.

Conclusions: The study suggests that the government of Pakistan should design new policies and funding schemes for developing and improving water availability.

Keywords: Rice output, Water availability, Agricultural GDP, OLS methods, Aromatic basmati Rice, And irrigation system
\end{abstract}

\section{Background}

Rice is the second major cash crop in Pakistan, which has a competitive advantage in production of aromatic basmati rice. As such, it is an important export for Pakistan, generating substantial revenues for the government through export duties, and the government has adopted different policies to promote adequate production. Punjab and Sindh are the major rice production provinces, accounting for $56 \%$ and $39 \%$ of total production, respectively (GOP, 2013).

Rice is also the most important food crop of Pakistan, even more so than wheat because despite wheat being also widely produced here, wheat yields are lower when compared to other countries such as China, France, and the United States (Ozpinar et al., 2006; Rehman et al., 2016a, 2016b, 2016c, 2016d). Tillage and weed infestation are the two major causes of low yield, decreasing the wheat yields by $50-80 \%$. Tillage is still the primary method used for weed control and preparing seedbeds in most areas worldwide. However, tillage practices alone are not adequate for weed management (Mohanty et al., 2006).

More recently, several techniques for rice cultivation have been introduced, including alternate wetting and drying, direct seeding, a mechanized system for rice amplification, and an aerobic rice system. These systems have been verified and scaled up in the

(c) The Author(s). 2017 Open Access This article is distributed under the terms of the Creative Commons Attribution 4.0 International License (http://creativecommons.org/licenses/by/4.0/), which permits unrestricted use, distribution, and reproduction in any medium, provided you give appropriate credit to the original author(s) and the source, provide a link to the Creative Commons license, and indicate if changes were made. 
provinces of Punjab and Sindh by the Pakistan Research Council (PARC), in cooperation with national and international research organizations (IRRI, 2010; Sharif, 2011). For a discussion on these technologies and systems, see Bouman et al. (2007) and Rehman et al. (2016a, 2016b, 2016c, 2016d).

We studied the performance of an aerobic rice system (ARS), where alternatively to transplanting seedlings, seeds are sown directly in the field. This system reduces cost per unit area, and is well suited for areas with labor shortages (Pandey et al., 2002; Pandey and Velasco, 2005). Furthermore, the availability of a wide range of weedicides decreases the labor required for weeding in this system (Farooq et al., 2011). Additionally, the system has methods of achieving irrigation requirements when groundwater drops below a critical level.

The overall performance of aerobic and direct seeded rice means they are potentially more profitable and environmentally maintainable as production systems. As such, the aerobic rice system may be an attractive alternative technological change in environments where water is scarce (Bouman et al., 2007).

\section{Literature review}

Rice is an important crop for many countries. Its cultivation extends from the humid tropics to northeastern China and southeastern Australia and from sea level to an altitude of over $2500 \mathrm{~m}$ in the more moderate regions of Nepal and Bhutan. Although most rice is cultivated in Asia, there are several suitable areas for its cultivation in Oceania and Europe. Due to the wide geographical distribution, rice is cultivated in many different climates and on a wide range of soils, with tremendous differences in soil properties. Early studies focused on flooded rice production in Asia due to these characteristically rice soils (IRRI, 1978; IRRI, 1985; Kawaguchi and Kyuma, 1977; Moormann and Breemen, 1978). However, most studies have focused on the specifics of waterlogged soil treatments (Banta and Mandoza, 1984; Kirk, 2004; Kögel-Knabner et al., 2010; Ladha et al., 1992; Ponnamperuma, 1972; Wassmann et al., 2000). As a result, recent studies examining the spatial representation and rice soil distribution are limited.

Consequently, comparable quantitative data on paddy soil quality and rice production systems are unavailable. In this context, important issues regarding to soil quality that require qualitative studies can usually be answered by local experts.

A better understanding of the spatial representation of soil quality and barriers to rice production could serve several purposes. To evaluate the target and focus on agricultural research, spatial information on environmental constraints to crop production can be used (Hijmans et al., 2003), and can additionally be assisted by communication technologies (Singh and Singh, 2010). Understanding the spatial distribution and properties of soil, climate, hydrology, and abiotic traits, with a focus on the importance of the target crop, can assist with specific challenges in rice production, such as finding more tolerant varieties of rice (Huang et al., 2010), as well as dealing with submergence tolerance (Xu et al., 2006), phosphorus deficiency tolerance (Gamuyao et al., 2012), and water stress tolerance (Verulkar et al., 2010). Similarly, this type of information can be used to improve the study and dissemination of management options and issues related to a particular soil. The sustainability of conventional rice systems is susceptible to water supply issues and deteriorating energy resources. For this purpose, resource conservation technologies 
(RCTs) are being developed and disseminated to promote global rice production (CGIAR, 2010).

Rice production technology has shown significant potential of improving resource utilization by planting rice in a manner similar to other crops, that is, in non-banks and non-flooded areas, such as unsaturated soils under wheat and maize, or the drought sowing of upland rice. Additionally, aerobic rice varieties are developed by crossing traditional lowland and upland varieties to combine yield potential traits of lowland varieties and adaptation to aerobic soils (Atlin et al., 2006) of upland varieties. ARS has been established in temperate climates and there is being work done to improve these systems in tropical and subtropical regions to increase the incomes of local farmers, as well as regional and national food security (Maclean et al., 2002; Prasad and Donald, 2011).

Another technology of rice cultivation is paddy rice, which is typically grown by transplanting 25- to 35-day-old seedlings in well-prepared puddled soils. This controls purification and weed growth and infestation, but requires tremendous amounts of fresh water for proper growth. Growing paddy rice in Pakistan is a formidable challenge for food security, where limited water reservoirs and increasing population are important barriers (Briscoe and Qamar, 2009).

According to one estimate, during the fiscal year 2011-2012 (July 1 to June 30), the availability of water from canal irrigation was around $10 \%$ less than the long-term average water use of 128 billion $\mathrm{m}^{3}$ (GOP, 2012). The groundwater table is falling at the rate of nearly $0.3 \mathrm{~m}$ per year (Hussain, 2002) due to increasing groundwater exploitation and utilization of more than $7 \mathrm{~m}$ (Kahlown et al., 2007; Rehman et al., 2016a, 2016b, 2016c, 2016d). Increases in fuel prices have also resulted in high charges for pumping groundwater, thus causing a decline in net economic profits. Labor shortages are another factor impacting rice cultivation, and hampering production and causing delays in transplanting seedlings, when manual evacuation and transplantation are required. The existing limited labor force mainly consists of unskilled contracted women and teenagers, which results in a lack of quality assurance in addition to uneven plantations and economic densities below the agronomically optimal ones (Baloch et al., 2005; Chaudhary et al., 2001; Farooq et al., 2011).

According to a report published by FAO (2000), around 40\% of food is produced through irrigated agriculture, a practice that consumes around 69\% of all freshwater resources. Furthermore, world population growth is predicted to increase demand for cereals, including rice and wheat, by $1.27 \%$ annually between 2000 and 2025 (Rosegrant and Cai, 2000). To achieve this projected food demand, an incremental increase of $17 \%$ in freshwater resources for irrigated agriculture would be needed (Seregeldin, 1999). To fulfill the requirements of an increasing population, pressure has been placed on the agricultural sector in both agricultural and semi-agricultural countries to produce higher yields where population growth is high and availability of freshwater bodies is low, further intensifying water consumption to produce more for an increasing population. This trend drives the bulk production of cereals, especially rice and wheat, to use inadequate amounts of irrigation.

Pakistan is expected to suffer a scarcity of irrigation water in the near future. Here, farmers generally utilize an open flooded system to irrigate fields in bundled units, resulting in poor water uniformity, long irrigation events, and over-irrigation (Kahlown and Kemper, 2004; Rehman et al., 2016a, 2016b, 2016c, 2016d). 
The tendency to rely on standing water during the growing season as to exploit rice yields has led to poor water use efficiency. Numerous studies on Pakistan revealed that 13-18 cm of water is applied per irrigation, which is considerably higher than the consumptive use of around $8 \mathrm{~cm}$ between irrigation events (Kahlown et al., 2001). Additionally, farm irrigation efficiency ranges between 23 and 70\% (Clyma and Ashraf, 1975; Kahlown et al., 1998; Kijne and Kuper, 1995). Furthermore, the use of a pressurized irrigation method has allowed planting of rice and wheat in different countries. Sprinkler irrigation, such as portable rain, guns can be used to add water depth, and sprinklers have been used under prevailing climatic conditions on the Indian subcontinent to improve farm irrigation efficiency by up to $80 \%$.

The areas under rice crop production per 1000 ha and yields in $\mathrm{kg} / \mathrm{ha}$ for Pakistan are shown in Figs. 1 and 2.

\section{Methods}

This study is based on time series data. The annual time series data pertaining to the agricultural gross domestic product (GDP), rice crop output, area under rice crop production, and water availability, from 1970 to 2015, were collected from the National Food Security and Research, Economic Survey of Pakistan, and Pakistan Bureau of Statistics (various publications).

\section{(a) Model Specification}

To examine the relationship between the agricultural GDP and rice crop output, area under rice crop production, and water availability, the following model was used:

$$
Y=A X_{1}^{\beta 1} X_{2}^{\beta 2} X_{3}^{\beta 3} \text { (1). }
$$

Taking the natural logarithm of eq. (1) and considering three explanatory variables, eq. (1) was converted to:

$$
\operatorname{Ln} Y=\beta 0+\beta 1 \operatorname{Ln} X 1+\beta 2 \operatorname{Ln} X 2+\beta 3 \operatorname{Ln} X 3+\mu(2) \text {. }
$$

Where.

$\beta O=$ Natural logarithm of A (intercept);

ln $Y=$ Natural logarithm of the agricultural GDP per year (in millions PKR);

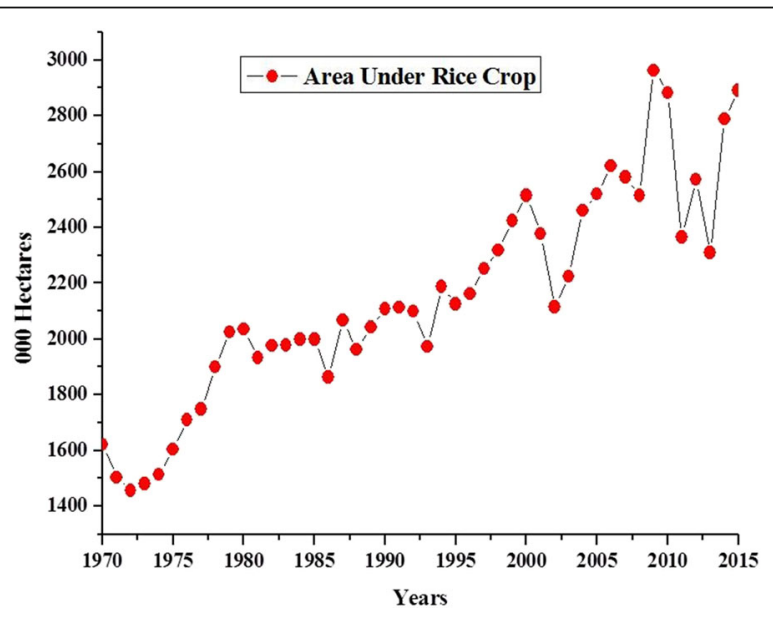

Fig. 1 Area under Rice Crop Production 1970-2015 


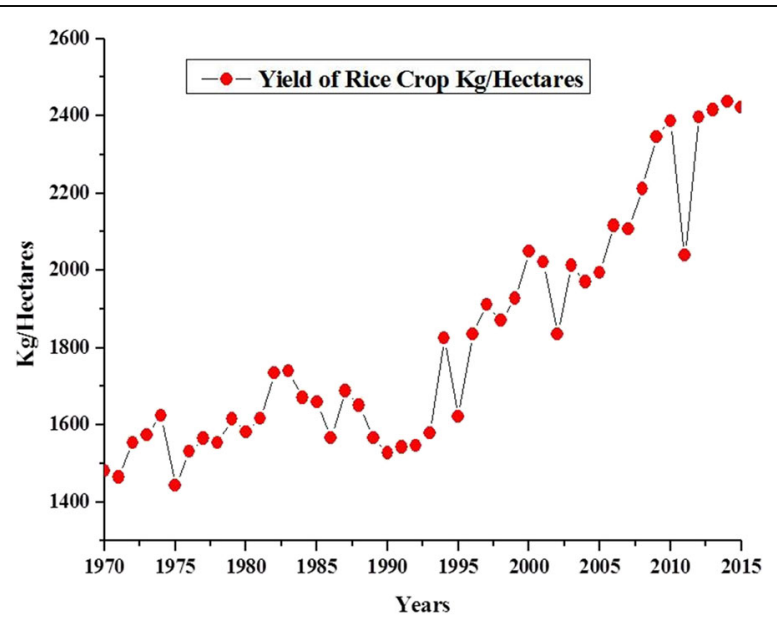

Fig. 2 Yield of Rice Crop in kg/ha 1970-2015

$\ln X_{1}=$ Natural logarithm of output of rice (in thousand tons);

$\ln X 2$ = Natural logarithm of area under rice crop production (in thousand hectares);

$\ln X 3$ = Natural logarithm of water availability (in million acre-feet);

$\mu=$ error term.

As such, eq. (2) can also be written as follows:

$\ln (A G R G D P)=\beta 0+\beta 1 \ln ($ OPRICE $)+\beta 2 \ln (A R R I C E)+\beta 3 \ln (W A)+\mu(3)$.

To check for the stationarity of study variables, we first tested for unit root using the augmented Dickey and Fuller (1981) unit root test. After checking for stationarity, the long-term relationships between dependent and independent variables were tested using the Johansen cointegration test. Finally, ordinary least square (OLS) was used to examine the impact of rice output, area under rice crop production, and water availability on the agricultural GDP of Pakistan for 1970-2015.

\section{Results and discussion}

\section{(a) Unit Root Test}

Table 1 Results of ADF unit root test including (trend and intercept)

\begin{tabular}{|c|c|c|c|c|}
\hline \multirow[t]{2}{*}{ Variables } & \multicolumn{2}{|l|}{ At level } & \multicolumn{2}{|c|}{ First difference } \\
\hline & t-Statistic & Critical values & t-Statistic & Critical values \\
\hline LnAGR & $\begin{array}{l}-2.123963 \\
(0.5189)\end{array}$ & $\begin{array}{l}1 \%-4.175640 \\
5 \%-3.513075 \\
10 \%-3.186854\end{array}$ & $\begin{array}{l}-6.967641^{*} \\
(0.0000)\end{array}$ & $\begin{array}{l}1 \%-4.180911 \\
5 \%-3.515523 \\
10 \%-3.188259\end{array}$ \\
\hline LnOPRICE & $\begin{array}{l}-4.327917^{*} \\
(0.0067)\end{array}$ & $\begin{array}{l}1 \%-4.175640 \\
5 \%-3.513075 \\
10 \%-3.186854\end{array}$ & $\begin{array}{l}-4.260702^{*} \\
(0.0092)\end{array}$ & $\begin{array}{l}1 \%-4.226815 \\
5 \%-3.536601 \\
10 \%-3.200320\end{array}$ \\
\hline LnARRICE & $\begin{array}{l}-6.570315^{*} \\
(0.0000)\end{array}$ & $\begin{array}{l}1 \%-4.175640 \\
5 \%-3.513075 \\
10 \%-3.186854\end{array}$ & $\begin{array}{l}-5.999122^{*} \\
(0.0001)\end{array}$ & $\begin{array}{l}1 \%-4.192337 \\
5 \%-3.520787 \\
10 \%-3.191277\end{array}$ \\
\hline LnWA & $\begin{array}{l}-1.812550 \\
(0.6812)\end{array}$ & $\begin{array}{l}1 \%-4.186481 \\
5 \%-3.518090 \\
10 \%-3.189732\end{array}$ & $\begin{array}{l}-8.746813^{*} \\
(0.0003)\end{array}$ & $\begin{array}{l}1 \%-4.186481 \\
5 \%-3.518090 \\
10 \%-3.189732\end{array}$ \\
\hline
\end{tabular}

* denotes rejection of the hypothesis is at the 0.05 level 
Table 2 Johansen co-integration test using trace statistic

\begin{tabular}{lllll}
\hline Johansen co-integration test using Trace Statistic & & & \\
\hline Hypothesized No. of CE(s) & Eigenvalue & Trace statistic & 5 Percent critical value & Prob $^{\text {b }}$ \\
\hline None $^{\text {a }}$ & 0.505093 & 59.27039 & 47.85613 & 0.0030 \\
At most 1 & 0.357834 & 29.02483 & 29.79707 & 0.0612 \\
At most 2 & 0.174253 & 9.979754 & 15.49471 & 0.2823 \\
At most 3 & 0.039806 & 1.746665 & 3.841466 & 0.1863 \\
\hline
\end{tabular}

Trace test indicates 1 co-integrating equation at the 0.05 level, ${ }^{\mathrm{a}}$ denotes rejection of the hypothesis is at the 0.05 level, ${ }^{b}$ Indicates values are accurate

The ADF unit root test, including trend and intercept, was used to verify the stationarity of each variable. The estimated results of the ADF test reported in Table 1 revealed that (AGRGDP) and (WA) are non-stationary in their level form, while (OPRICE) and (ARRICE) are stationary. However, we rechecked AGRGDP and WA, and found they became stationary after taking the first difference I (1), since the values of the ADF statistics test are above critical values at the $5 \%$ significance level.

\section{(b) Cointegration Test}

Following the ADF unit root test analysis, we analyzed the long-term relationship between agricultural GDP and rice output, area under rice crop production, and water availability using the Johansen cointegration test, including trace and MaxEigen statistics. Tables 2 and 3 show the results of the cointegration analysis, values of trace statistics (59.27039), and of Max-Eigen statistics (30.24556), which are above than their critical values of (47.85613) and (27.58434), indicating a long-term relationship between dependent and independent variables. This means rejecting the null hypothesis of no cointegration. Both trace and Max-Eigen statistics reveal one cointegrating equation at the $5 \%$ level.

(c) Regression Analysis

To investigate the relationship between the variables rice crop output of rice crop, area under rice crop production, and water availability with the agricultural GDP of Pakistan, OLS was applied. The results of the regression analysis are presented in Table 4, showing a high value of R2 of 0.832 or $83.2 \%$. This implies that around $83.2 \%$ of the total variation in agricultural GDP can be explained by the three independent variables. The computed value of the F-statistic is 69.52981, with a probability value of 0.000000 , which indicates the fitness of the overall model.

The results of the regression analysis show the coefficient of output of rice is highly significant at both the $1 \%$ and $5 \%$ of significance levels, indicating a strong and positive relationship

Table 3 Johansen co-integration test using Max-Eigen Statistic

\begin{tabular}{|c|c|c|c|c|}
\hline Hypothesized No. of CE(s) & Eigenvalue & Max-eigen statistic & 5 Percent critical value & Prob $^{b}$ \\
\hline None $^{a}$ & 0.505093 & 30.24556 & 27.58434 & 0.0222 \\
\hline At most 1 & 0.357834 & 19.04508 & 21.13162 & 0.0955 \\
\hline At most 2 & 0.174253 & 8.233090 & 14.26460 & 0.3555 \\
\hline At most 3 & 0.039806 & 1.746665 & 3.841466 & 0.1863 \\
\hline
\end{tabular}

Max-eigenvalue test indicates 1 co-integrating equation at the 0.05 level, ${ }^{\text {a }}$ denotes rejection of the hypothesis is at the 0.05 level, ${ }^{b}$ Indicates values are accurate 
Table 4 Regression Analysis

\begin{tabular}{|c|c|c|c|c|}
\hline \multicolumn{5}{|c|}{$\begin{array}{l}\text { Regression Analysis } \\
\text { Dependent Variable: In (AGRGDP) } \\
\text { Method: Least Squares } \\
\text { Sample: 1970-2015 Included observations: } 46\end{array}$} \\
\hline $\bar{C}$ & -19.95344 & 2.325717 & -8.579480 & 0.0000 \\
\hline Ln (OPRICE) & 3.846489 & 0.536270 & 7.172672 & 0.0000 \\
\hline Ln (ARRICE) & 0.101659 & 0.259643 & 0.391535 & 0.6974 \\
\hline $\operatorname{Ln}(W A)$ & -0.032641 & 0.812751 & -0.040161 & 0.9682 \\
\hline R-squared & 0.832395 & \multicolumn{2}{|c|}{ Adjusted R-squared } & 0.820423 \\
\hline F-statistic & 69.52981 & \multicolumn{2}{|c|}{ Prob(F-statistic) } & 0.000000 \\
\hline \multicolumn{2}{|l|}{ Durbin-Watson stat } & \multicolumn{2}{|l|}{0.746296} & \\
\hline
\end{tabular}

between agricultural GDP and rice output. This means that every $1 \%$ increase in rice output increased agricultural GDP by 3.84\%. Our results, according to Anyanwu (2010), show a positive relationship between rice crop output and agricultural GDP. Further, the coefficient of the area under rice crop production is also highly significant at both the $1 \%$ and $5 \%$ of significance levels, indicating a significant and positive relationship between the area under rice production and agricultural GDP. This implies that every $1 \%$ increase in area under rice crop production leads to a $0.10 \%$ increase in agricultural GDP. Moreover, the results indicate a negative relationship between water availability and agricultural GDP. In Pakistan, agricultural productivity is much lower compared to developed countries due to low water availability.

\section{Conclusion and recommendations}

This study examined the relationship between the agricultural GDP of Pakistan and the rice crop output area under rice crop production, and water availability during 1970-2015. Time series data were collected from the National Food Security and Research, various issues of the Economic Survey of Pakistan, and the Pakistan Statistical Year Book. For analysis the ADF unit root test, Johansen cointegration test, and OLS were used. The results of the Johansen cointegration test revealed that a long-term relationship between rice crop output, area under rice crop production, and water availability with the agricultural GDP of Pakistan. The results of regression analysis showed that rice output and area under rice crop production have a positive and significant relationship with the agricultural GDP, while water availably has a negative relationship. Therefore, this study suggests and recommends that the government of Pakistan seeks out new policies and funding schemes for the development and improvement of water availability.

Authors' contributions

AR conceived the study, collected the data, and estimated the econometric model. $L$ and AAC drafted the manuscript, MS and $\mathrm{IH}$ read and made suggestions of the manuscript. All authors read and approved the final manuscript.

Competing interests

The authors declare that they have no competing interests in this study.

Publisher's Note

Springer Nature remains neutral with regard to jurisdictional claims in published maps and institutional affiliations. 


\section{Author details}

${ }^{1}$ College of Economics and Management, Anhui Agricultural University, Hefei, Anhui, China. ${ }^{2}$ College of Economics and Management, Sichuan Agricultural University, Sichuan, Yaan Shi, Sichuan Sheng, China. ${ }^{3}$ University of Kotli Azad Jammu \& Kashmir, Kotli, Pakistan. ${ }^{4}$ Allama Iqbal Open University, Islamabad 44000, Pakistan.

Received: 6 December 2016 Accepted: 18 July 2017

Published online: 26 July 2017

\section{References}

Anyanwu JC (2010) Poverty in Nigeria: a gendered analysis. Afr Stat J 11:38-61

Atlin GN, Lafitte HR, Tao D, Laza M, Amante M, Courtois B (2006) Developing rice cultivars for high-fertility upland systems in the Asian tropics. Field Crops Res 97:43-52

Baloch MS, Hassan GUL, Morimoto T (2005) Weeding techniques in transplanted and direct wet-seeded rice in Pakistan. Weed Biol Manage 5:190-196

Banta S, Mandoza CV (1984) Organic matter and Rice. International Rice Research Institute (IRRI), Los Baños, Philippines, p 631

Bouman BAM, Lampayan RM, Tuong TP (2007) Water Management in Irrigated Rice: coping with water scarcity. International Rice Research Institute (IRRI), Manila, Philippines, p 54

Briscoe J, Qamar U (2009) Pakistan's water economy running dry. Oxford University Press, USA

CGIAR. (2010). Sustainable Crop Productivity Increase for Global Food Security. In A CGIAR Research Program on Rice-Based Production Systems: (pp. 267)

Chaudhary, R. C., Tran, D. V., \& Duffy, R. (2001). Speciality Rices of the world: breed-ing, production and marketing. In. ROME, Italy: food and agriculture organization (FAO)

Clyma WA, Ashraf MM (1975) Irrigation practices and application efficiencies in Pakistan. In: Water management research project: water management technical report no. 39. Colorado State University, Fort Collins, Colorado, USA

Dickey DA, Fuller WA (1981) Likelihood ratio statistics for autoregressive time series with a unit root. Econometrica, p 49

FAO (2000) Crops and drops: making the best use of water for agriculture. FAO Advance Edition, Rome, Italy

Farooq M, Siddique KHM, Rehman H, Aziz T, Lee DJ, Wahid A (2011) Rice direct seeding: experiences, challenges and opportunities. Soil Tillage Res 111:87-98

Gamuyao R, Chin JH, Pariasca-Tanaka J, Pesaresi P, Catausan S, Dalid C, Slamet-Loedin I, Tecson-Mendoza EM, Wissuwa M, Heuer S (2012) The protein kinase Pstol1 from traditional rice confers tolerance of phosphorus deficiency. Nature 488:535-539

GOP (2013-2014) Pakistan economic survey 2000-01. In: Economic advisory wing finance division. Government of Pakistan, Islamabad, Pakistan

GOP (2012) Pakistan economic survey 2010-11. Economic Advisory Wing Finance Division, Government of Pakistan, Islamabad, Pakistan, In

Hijmans RJ, Condori B, Carillo R, Kropff MJ (2003) A quantitative and constraint specific method to assess the potential impact of new agricultural technology: the case of frost resistant potato for the Altiplano (Peru and Bolivia). Agric Syst 76:895-911

Huang Y, Lan Y, Thomson SJ, Fang A, Hoffmann WC, Lacey RE (2010) Development of soft computing and applications in agricultural and biological engineering. Comput Electron Agric 71:107-127

Hussain T (2002) Groundwater management: a case study of Rechna Doab -Pakistan. J Drain Water Manage 6:69-76

IRRI (1978) Rice and soils. International Rice Research Institute, Los Baños, Philippines, p 825

IRRI (1985) Wetland soils: characterization, classification, and utilization. International Rice Research Institute, Los Baños, Philippines, p 559

IRRI (2010) Developing and disseminating water-saving Rice Technologies in South Asia. International Rice Research Institute (IRRI), Manila, Philippines, p 58

Kahlown MA, Kemper WD (2004) Seepage losses as affected by condition and composition of channel banks. J Agric Water Manage 65:145-153

Kahlown MA, Raoof A, Hanif M (2001) Plant population effect on paddy yield. J Drain Water Manage 5:1-5

Kahlown MA, Raoof A, Zubair M, Kemper WD (2007) Water use efficiency and economic feasibility of growing rice and wheat with sprinkler irrigation in the Indus Basin of Pakistan. Agric Water Manag 87:292-298

Kahlown MA, Shafique MS, Iqbal M (1998) Improved irrigation methods for efficient use of irrigation water under different water-table depths. Mona Reclamation Experimental Project, WAPDA, Bhalwal

Kawaguchi, K., \& Kyuma, K. (1977). Paddy soils in tropical Asia: their material nature and fertility. In Monographs of the Center for Southeast Asian StudiesKyoto University: (pp. 258)

Kijne JW, Kuper M (1995) Salinity and sodicity in Pakistan's Punjab: a threat to sustainability of irrigated agriculture? J Int Water Resour Dev 11:73-86

Kirk GJD (2004) The biogeochemistry of submerged soils. John Wiley \& Sons, Chichester, UK

Kögel-Knabner I, Amelung W, Cao Z, Fiedler S, Frenzel P, Jahn R, Kalbitz K, Kölbl A, Schloter M (2010) Biogeochemistry of paddy soils. Geoderma 157:1-14

Ladha JK, George T, Bohlool BB (1992) Biological nitrogen fixation for sustainable agriculture. Kluwer Academic Publishers, Dordrecht, Neatherlands

Mohanty M, Painuli DK, Misra AK, Bandyopadhyaya KK, Ghosh PK (2006) Estimating impact of puddling, tillage and residue management on wheat (Triticum Aestivum L.) seedling emergence and growth in a ricewheat system using nonlinear regression models. Soil Tillage Res 87:119-130

Maclean JL, Dawe D, Hardy B, Hettel GP (2002) Rice Almanac. International Rice Research Institute (IRRI), Manila, Philippines

Moormann FR, Breemen NV (1978) Rice: soil, water, land. International Rice Research Institute (IRRI), Los Baños, Philippines, p 185

Ozpinar S (2006) Effects of tillage on productivity of a winter wheat-vetch rotation under dry land Mediterranean conditions. Soil Tillage Res 89:258-265

Pandey S, Mortimer M, Wade L, Tuong TP, Lopez K, Hardy B (2002) Direct seed-ing: research issues and opportunities. In: International workshop on direct seeding in Asian Rice systems: strategic research issues and opportunities. International Rice Research Institute, Bangkok, Thailand, LosBãnos (Philippines), p 383 
Pandey S, Velasco L (2005) Trends in crop establishment methods in Asia and research issues. In: Rice is life: scientific perspectives for the 21st century, pp 178-181

Ponnamperuma FN (1972) The chemistry of submerged soils. Advances Agronomy 24:29-96

Prasad, R., \& Donald, L. S. (2011). Aerobic Rice Systems. In Advances in Agronomy: Academic Press: (pp. 207-247)

Rehman, A., Jingdong, L., Chandio, A. A., Hussain, I., Wagan, S. A., \& Memon, Q. U. A. (2016b). Economic perspectives of cotton crop in Pakistan: A time series analysis (1970-2015)(Part 1). J Saudi Soc Agric Sci. doi: 10.1016/j.jssas.2016.12.005

Rehman, A., Jingdong, L., Khatoon, R., \& Hussain, I. (2016d). Modern Agricultural Technology Adoption its Importance, Role and Usage for the Improvement of Agriculture. DOI: 10.5829/idosi.aejaes.2016.16.2.12840

Rehman, A., Jingdong, L., Shahzad, B., Chandio, A. A., Hussain, I., Nabi, G., \& Iqbal, M. S. (2016a). Economic perspectives of major field crops of Pakistan: An empirical study. Pacific Science Review B: Humanities and Social Sciences. doi: 10.1016/j.psrb.2016.09.002

Rehman A, Jingdong L, Du Y, Khatoon R, Wagan SA, Nisar SK (2016c) Flood disaster in Pakistan and its impact on agriculture growth (a review). Environ Dev Econ 6(23):39-42

Rosegrant MW, Cai X (2000) Modeling water availability and food security_a global perspective: the IMPACT-water model. In: Working Draft. International Food Policy Research Institute, Washington, DC

Seregeldin I (1999) Looking ahead: water, life and the environment in the 21st century. J Int Water Resour Dev 15:17-27

Sharif A (2011) Technical adaptations for mechanized SRI production to achieve water saving and increased profitability in Punjab, Pakistan. Paddy Water Environ 9:111-119

Singh, A. N., \& Singh, U. S. (2010). Targeted dissemination of stress-tolerant rice varieties: propagating Swarna-Sub1, Sahbhagi Dhan, and CSR36 in Uttar Pradesh, India. In (Vol. 3,4): STRASA NEWS

Verulkar SB, Mandal NP, Dwivedi JL, Singh BN, Sinha PK, Mahato RN, Swain P, Dongre P, Payasi D, Singh ON, Bose LK, Robin S, Chandrababu R, Senthil S, Jain A, Shashidhar HE, Hittalmani S, Cruz CV, Paris T, Robert H, Raman A, Haefele SM, Serraj R, Atlin G, Kumar A (2010) Breeding resilient and productive genotypes adapted to drought prone rainfed ecosystem of India. Field Crops Res 117:197-208

Wassmann, R., Lantin, R. S., \& Neue, H. U. (2000). Methane emissions from major rice ecosystems. Special Issue of 'Nutrient Cycling in Agroecosystems' (Vol. 58)

Xu K, Xu X, Fukao T, Canlas P, Maghirang-Rodriguez M, Heuer S, Ismail AM, Bailey-Serres J, Ronald PC, Mackill DJ (2006) Sub1A is an ethylene-response-factor-like gene that confers submergence tolerance to rice. Nature 442:705-708

Submit your manuscript to a SpringerOpen ${ }^{\circ}$ journal and benefit from:

- Convenient online submission

- Rigorous peer review

- Open access: articles freely available online

- High visibility within the field

- Retaining the copyright to your article 